\title{
Environmental hydrochemical and stabile isotope methods used to characterise the relation between karst water and surface water
}

\section{Metodologie idrochimiche ambientali e isotopiche per la caratterizzazione delle relazioni tra acque carsiche e superficiali}

\author{
Romeo Eftimi, Tete Akiti, Sokrat Amataj, Ralf Benishke, Hans Zojer, Jovan Zoto
}

\begin{abstract}
Riassunto: Gli acquiferi carsici sono caratterizzati da forte eterogeneità nel flusso sotterraneo. I metodi classici di studio quali sondaggi, prove di pompaggio e singoli punti di osservazione forniscono importanti dati, ma non possono essere rappresentativi di tutto l'acquifero. Le metodologie analitiche idrochimiche ambientali e isotopiche possono comunque restituire importanti informazioni circa la caratterizzazione di grandi corpi acquiferi. Alcuni casi di studio dell'Albania, presentati in questo lavoro, dimostrano come l'utilizzo degli isotopi stabili sia molto efficace specialmente se usati in combinazione con le metodologie idrochimiche, nell'identificazione delle aree di ricarica delle acque carsiche. Tra le metodologie isotopiche, l'effetto della quota altimetrica sembra essere maggiormente indicativo per la soluzione di questo problema.

Per la caratterizzazione della litologia delle rocce carsiche e degli aspetti fisici degli acquiferi carsici (tipologia del flusso sotterraneo), l'uso combinato di alcuni parametri idrochimici, quali, la conducibilità elettrica, la durezza totale, il rapporto $\mathrm{rCa} / \mathrm{rMg}, \mathrm{RSO}_{4} /$ $\mathrm{rMg}$, la pressione della $\mathrm{CO}_{2}$ e gli indici di calcite e silice $\left(\mathrm{Si}_{c}\right)$ e la saturazione della dolomite $\left(\mathrm{Si}_{\mathrm{d}}\right)$, sono risultati molto efficaci.
\end{abstract}

Keywords: stable isotope methods, hydrochemical methods, recharge sources, karst aquifers, Albania.

Parole chiave: metodi degli isotopi stabili, metodi idrochimici, aree di ricarca, acquiferi carsici, Albania.

Romeo EFTIMI 㪯”

Geological Service of Albania, Tirana, Albania

eftimiromeo@gmail.com

Tete AKITI

IAEA, former expert. Isotope Hydrology Section

\section{Sokrat AMATAJ}

Jovan ZOTO

Institut of Nuclear Physics, Tirana, Albania

Ralf BENISHKE

Hans ZOJER

Institute of Applied Geosciences, Graz University of Technologr, Graz, Austria

Ricevuto/Received: 13 January 2017-Accettato Accepted: 16 March 2017 Pubblicato online /Published online: 31 March 2017

This is an open access article under the CC BY-NC-ND license: http://creativecommons.org/licenses/by-nc-nd/4.0/

(C) Associazione Acque Sotterranee 2017
Abstract: Karst aquifers are characterized by high heterogeneity of groundwater flow. The classical study methods such as boreholes, pumping tests, and point observations give important data but cannot be extended to the entire aquifer. However the environmental bydrochemical and stabile isotope methods could give important information about large scale aquifer characterization. Some study examples from Albania, shown in this paper, demonstrate the successful application of the isotope methods, which are more powerful if applied in combination with hydrochemical ones, for the identification of the karst water recharge sources. Among the isotope methods the altitude effect seems to be more indicative for the solution of the problem concerned. For characterising the lithology of karst rocks and the physical aspects of karst aquifers (type of groundwater flow) the combined use of some hydrochemical parameters like the water conductivity, total hardness, ionic ratios $r \mathrm{Cal}$ $r \mathrm{Mg}, r \mathrm{SO}_{4} / \mathrm{r} / \mathrm{mg}, \mathrm{CO}_{2}$ pressure and the indexes of calcite and ( $\mathrm{Si}_{\mathrm{c}}$ ) and of dolomite saturation $\left(S i_{d}\right)$, result very useful.

\section{Introduction}

Karst aquifers have complex and original characteristics which make them very different from the other aquifers in their high heterogeneity created and organised by groundwater flow (Bakalowicz 2005). The high heterogeneity and low predictability of karst aquifers make karst water investigation often a difficult task. The classical study methods such as boreholes, pumping tests, and point observations give important data but cannot be extended to the entire aquifer. Hydrochemical and isotope data are useful in identifying sources of recharge to groundwater systems and in tracing ground-water flow (Glynn PD and Plumer LN 2005, Cervi et al. 2015). The spring hydrographs also could provide the behaviour of important aquifer characteristics (Malik 2007, Malik and Vojtková 2008).

Most important of stable isotopes used for solving of the hydrologic problems appear to be oxygen-18 and deuterium expressed as $\delta^{18} \mathrm{O}$ and $\delta \mathrm{D}$ (Bradley at al. 1972; IAEA 1981, 1983, 1989; IAEA-IHLS 2004). There are two important characteristics which make stable isotopes very useful for these applications, namely: a) the distinct isotopic composition of the waters from different geographic origins (mainly different elevations) or hydrologic nature, and b) the conservation of the isotopic content of the water in the groundwater bodies (Gat and Dansgaard, 1970). In a given region, the $\delta$-values of precipitation at higher altitudes are generally more negative (more depleted on isotopes). Gradients for $\delta^{18} \mathrm{O}$ between 0.15 and $0.5 \% / 100 \mathrm{~m}$ and the gradients for $\delta \mathrm{D}$ between about 1.5 and $4.0 \%$ are considered to be typical (Payne et al. 1978; IAEA 1981), which is conformed also by other studies: -0.31 for 
Piemont area (Bortolami et al. 1979), -0.21 for Rumania (Tenu and Davidescu 1983), -0.21 for Northern Greece (Leontiadis et al. 1996, 1997) and -0.23 for Syria (Kattan 1997). Solution of many problems about the groundwater origin depends on the altitude effect. In many cases, the isotopic composition of meteoric groundwater is found to match the mean composition of precipitation over the recharge area to a fair approximation. Particularly useful for the identification of the karst water recharge sources are the so called local springs at which the recharge area elevation coincides with their mean geographical elevation of the small watersheds.

Two processes could change the isotopic composition of the surface and ground waters, namely a) the mixing with other types of water and b) the evaporation. Many practical hydrologic problems could successfully be resolved if during the study clear evidence is obtained about the change in isotopic composition of the water due to the mixing or evaporation (IAEA 1981, 1983; Clark and \& Fritz 1997; Mazor 1985; Aggarwal et al. 2005).

In the paper are included two studies about the relation of

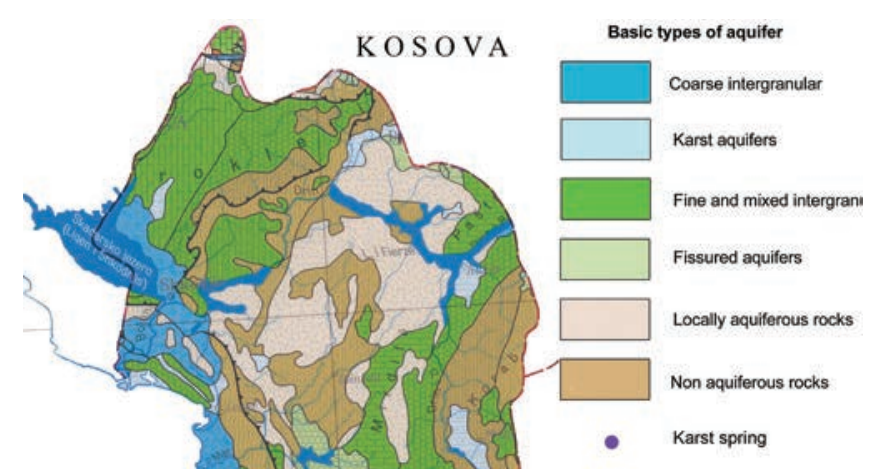

FYROM

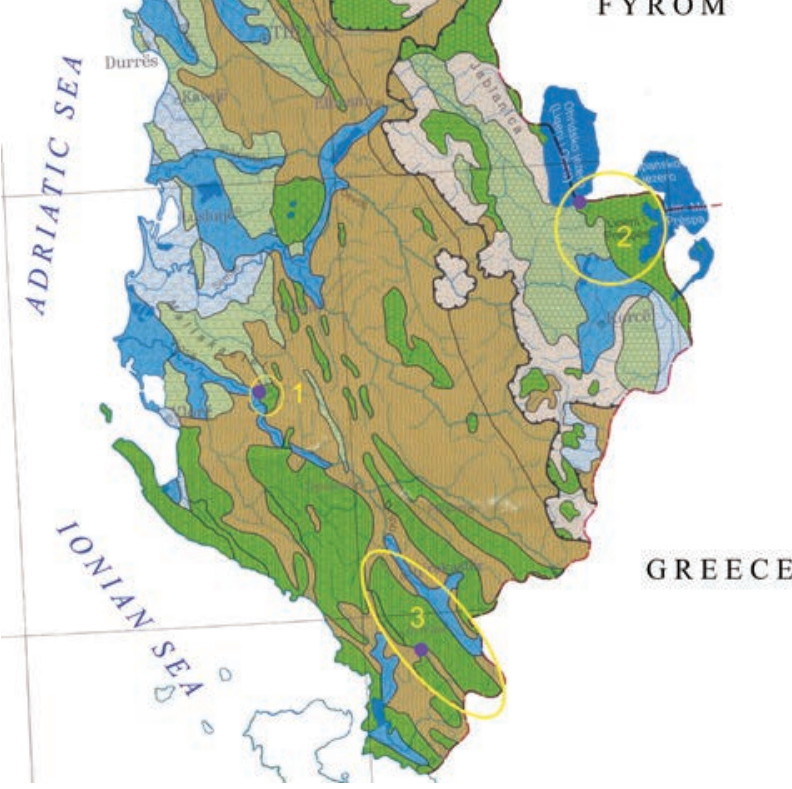

Fig. 1 - Skematic hydrogeological map of Albania and location of study areas: 1. Poçemi springs; 2. Prespa and Ohrid lakes; 3. Bistrica springs.

Fig. 1 - Carta idrogeologica schematica dell'Albania con l'ubicazione delle aree di studio: 1) sorgenti di Poçemi; 2) laghi di Prespa e Ohrid; 3) sorgenti di Bistrica. hydrochemistry to the lithology and physical aspect of karst aquifers, and three investigations related to the identification of the different recharge sources of some big karst springs Poçemi, Tushemisht and Bistrica (Fig. 1).

\section{Relation between hydrochemistry and lithology of karst rocks}

A hydrochemical study of karst water performed on four karst areas of Albania (Eftimi 1998, 2005) and one performed in Bulgaria (Eftimi and Benderev 2007) show a clear relation of the karst water chemistry to the lithology of the rocks. In the same time the chemistry of the springs is controlled also by travel time of the water reaching the springs and the relation between chemistry and lithology could be used in the context of site hydrogeology (Scanlon and Thrailkill 1987). Physical and chemical data were collected at 25 springs of Albania which mean discharge vary from about $10 \mathrm{l} / \mathrm{s}$ to more than $1000 \mathrm{l} / \mathrm{s}$. On the site was measured the water temperature, $\mathrm{pH}$ and electrical conductivity (EC), while the chemical parameters are determined in the laboratory.

The hydrogeological data and the chemical parameters and computed Sic and Sid and equilibrium $\mathrm{CO}_{2}$ pressures values for the investigated spring waters are generalized in Table 1 and in the graphics of $\mathrm{rCa} / \mathrm{rMg}$ versus $\mathrm{rCa}+\mathrm{rMg}$ (Fig. 2) and of $\mathrm{Si}_{\mathrm{c}}$ versus $\mathrm{Si}_{\mathrm{d}}$ (Fig. 3). Essential differences in chemistry exist among spring waters of karst massifs with different lithology.

The spring waters of pure limestone of Mali me Gropa have low hardness, low $\mathrm{SO}_{4}{ }^{2-}$ concentrations, and therefore also a low EC. In these waters, the ratio $\mathrm{rCa} / \mathrm{rMg}$ has high value, and in opposite of this the ratio $\mathrm{rSO}_{4} / \mathrm{rMg}$ has lower values.

The dolomite waters of Dajti massif are hard; they have relative high $\mathrm{EC}$ and high $\mathrm{SO}_{4}{ }^{2-}$ concentrations, coming probably from the oxidation of the trace pyrite and marcasite and of trace gypsum present in dolomites of the investigated massif.

The water of Blue Eye spring in Mali Gjere massif is hard; the concentration of $\mathrm{SO}_{4}{ }^{2-}$ is about $135 \mathrm{mg} / \mathrm{l}$ and $\mathrm{EC}$ is relatively high. The spring water is saturated with respect to calcite and is near saturated with respect to dolomite. The main $\mathrm{SO}_{4}{ }^{2-}$ source for the Blue Eye spring water is the sulphate waters of nearby Drinos Valley partially recharging this spring. This contributes also to the increase of $\mathrm{rSO}_{4} / \mathrm{rMg}$ ratio of Blue Eye spring water up to 5.4 .

It is already known that $\mathrm{rCa} / \mathrm{rMg}$ ratio in groundwater has a clear geochemical implication; their values are usually lower in dolomite and higher in limestone (Langmuir 1971, 1986; Zötel 1974; Zojer and Stichler 1988). As shows the graphic on Fig. 2 an indirect correlation exist between the $\mathrm{rCa} / \mathrm{rMg}$ ratios and the sums of $\mathrm{rCa}+\mathrm{rMg}$, while the sulphate waters are "displaced" from the "correlation" curve. The data indicate that although most of limestone springs are under-saturated with respect to calcite and dolomite, the amount of undersaturation with respect to dolomite is much greater than that with respect to calcite (Fig. 2). This is explained with the higher solution of calcite in comparison with dolomite (Thrailkill 1976, 1977; Appelo and Postma 1999). 
Tab. 1 - Chemical data of the investigated karst springs. The numbers in the upper line show the range and the number in the lower line shows the average value.

Tab. 1 - Dati chimici delle sorgenti carsiche investigate. I numeri nella linea superiore mostrano l'intervallo tra minimo e massimo valore, quelli nella riga sottostante indicano i valori medi.

\begin{tabular}{|c|c|c|c|c|c|c|}
\hline \multirow[b]{2}{*}{ Parameters } & \multirow[b]{2}{*}{ Unity } & \multicolumn{5}{|c|}{ Karst massifs } \\
\hline & & Dajti & Mali me Gropa & Tomori & $\begin{array}{l}\text { Iskrec- } \\
\text { Bulgaria }\end{array}$ & Mali Gjere \\
\hline Lithology & & Dolomite & Pure Limestone & $\begin{array}{l}\text { Limestone, less } \\
\text { dolomite }\end{array}$ & $\begin{array}{l}\text { Limestone, less } \\
\text { dolomite }\end{array}$ & $\begin{array}{l}\text { Limestone partially recharged by } \\
\mathrm{SO}_{4} \text { water }\end{array}$ \\
\hline Nr. of springs & & 15 & 5 & 7 & 1 & 1 \\
\hline Nr. of analyses & & 20 & 15 & 8 & 30 & 35 \\
\hline Chemical facie & & $\mathrm{HCO}_{3}-\mathrm{SO}_{4}-\mathrm{Mg}$ & $\mathrm{HCO}_{3}-\mathrm{Ca}$ & $\mathrm{HCO}_{3}-\mathrm{Ca}$ & $\mathrm{HCO}_{3}-\mathrm{Ca}$ & $\mathrm{SO}_{4}-\mathrm{Ca}$ \\
\hline Temperature & ${ }^{\circ} \mathrm{C}$ & $\begin{array}{c}11.7 \div 18.8 \\
14,4\end{array}$ & $\begin{array}{c}5.8 \div 8.1 \\
6,6\end{array}$ & $\begin{array}{c}8.5 \div 11.5 \\
9,4\end{array}$ & $\begin{array}{c}8.5 \div 11.6 \\
9,9\end{array}$ & $\begin{array}{c}12.2-12.4 \\
12,3\end{array}$ \\
\hline $\mathrm{pH}$ & & $\begin{array}{c}7.20 \div 7.70 \\
7,45\end{array}$ & $\begin{array}{c}7.42 \div-7.88 \\
7,55\end{array}$ & $\begin{array}{c}7.43 \div 8.72 \\
7,98\end{array}$ & $\begin{array}{c}7.1 \div 7.55 \\
7,43\end{array}$ & $\begin{array}{c}7.60-7.67 \\
7,64\end{array}$ \\
\hline $\mathrm{SO}_{4}^{2-}$ & $\mathrm{mg} / \mathrm{l}$ & $\begin{array}{c}10.6 \div 309.0 \\
83\end{array}$ & $\begin{array}{c}5.4 \div 12.4 \\
8,2\end{array}$ & $\begin{array}{c}5.8 \div 26.3 \\
10,6\end{array}$ & $\begin{array}{c}8.7 \div 33.9 \\
18\end{array}$ & $\begin{array}{c}118.6-135.7 \\
131,1\end{array}$ \\
\hline $\begin{array}{c}\text { Electric } \\
\text { Conductivity-EC }\end{array}$ & $\mu \mathrm{S} / \mathrm{cm}$ & $\begin{array}{c}347 \div 863 \\
542\end{array}$ & $\begin{array}{c}145 \div 222 \\
207\end{array}$ & $\begin{array}{c}224 \div 391 \\
271\end{array}$ & & $\begin{array}{c}535-594 \\
574\end{array}$ \\
\hline TDS & $\mathrm{mg} / \mathrm{l}$ & $\begin{array}{c}230 \div 682 \\
355\end{array}$ & $\begin{array}{c}109 \div 153 \\
138\end{array}$ & $\begin{array}{c}135 \div 234 \\
168\end{array}$ & & $\begin{array}{c}370-399 \\
390\end{array}$ \\
\hline Total hardness & $\mathrm{mg} / \mathrm{eqv} / \mathrm{l}$ & $\begin{array}{c}3.86 \div 9.56 \\
5,5\end{array}$ & $\begin{array}{c}1.47 \div 2.77 \\
2,2\end{array}$ & $\begin{array}{c}2.40 \div 4.11 \\
2,9\end{array}$ & $\begin{array}{c}2.30 \div 4.23 \\
3,17\end{array}$ & $\begin{array}{c}5.57-5.94 \\
5,8\end{array}$ \\
\hline $\mathrm{rCa} / \mathrm{rMg}$ & & $\begin{array}{c}1.2 \div 3.4 \\
2,1\end{array}$ & $\begin{array}{c}7.2 \div 13.8 \\
11,8\end{array}$ & $\begin{array}{c}2.4 \div 9.0 \\
5,6\end{array}$ & $\begin{array}{c}1.81 \div 5.50 \\
2,98\end{array}$ & $\begin{array}{c}4.9-5.7 \\
5,4\end{array}$ \\
\hline $\mathrm{rSO}_{4} / \mathrm{rMg}$ & & $\begin{array}{c}1.6 \div 119 \\
0,95\end{array}$ & $\begin{array}{c}0.6 \div 2.0 \\
1,1\end{array}$ & $\begin{array}{c}0.5 \div 1.7 \\
0,9\end{array}$ & & $\begin{array}{c}5.1-6.6 \\
5,4\end{array}$ \\
\hline $\log \mathrm{P}_{\mathrm{CO}_{2}}$ & $10^{\mathrm{x}} \mathrm{atm}$ & $-1.92 \div-2.41$ & $-2.38 \div-2.81$ & $-2.32 \div-3.06$ & & $-2.53 \div-3.28$ \\
\hline $\mathrm{Si}_{\mathrm{C}}$ & & $0.37 \div-0.08$ & $-0.46 \div-0.04$ & $-0.28 \div-0.09$ & $-0.88 \div-0.25$ & $-0.26 \div-0.29$ \\
\hline $\mathrm{Si}_{\mathrm{d}}$ & & $-0.26 \div-0.125$ & $-0.68 \div-1.0$ & $-0.65 \div-0.04$ & & $-0.13 \div-0.09$ \\
\hline
\end{tabular}

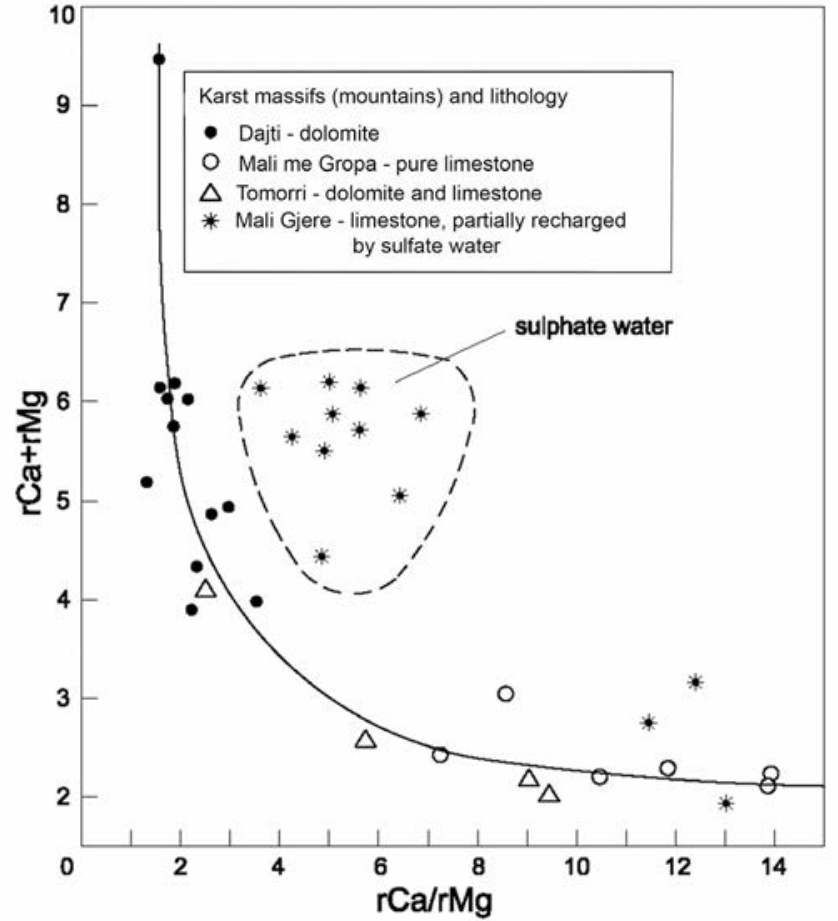

Fig. $2-r C a / r M g$ versus $r C a+r M g$.

Fig. 2 - Relazione tra rCa/rMg e rCa+rMg.

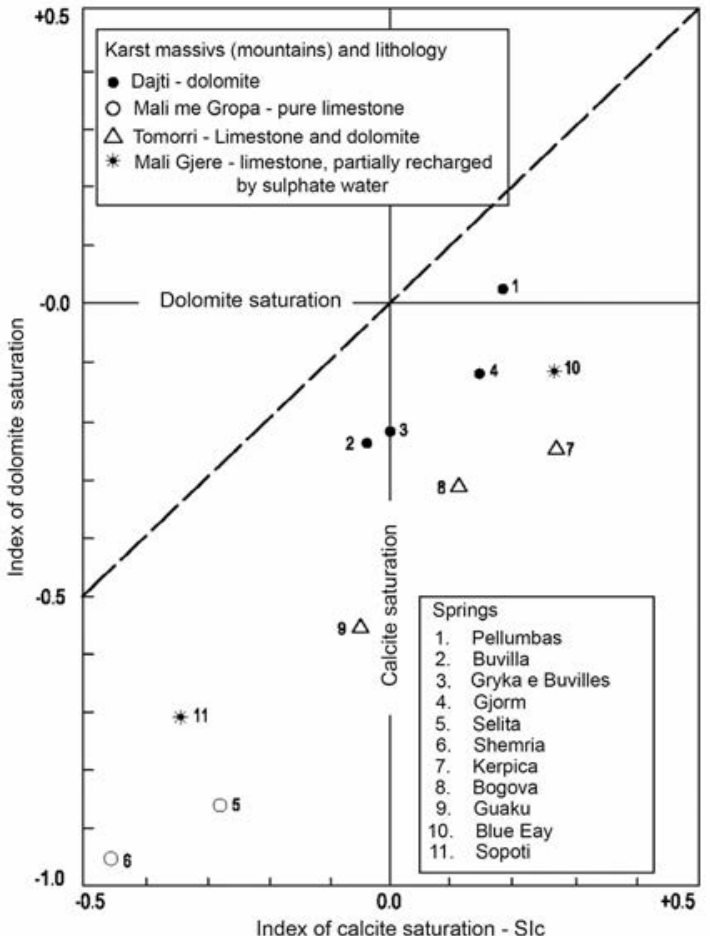

Fig. 3 - Si $i_{c}$ versus $S i_{d}$ for karst springs of different litholigy.

Fig. 3 - Relazione tra $\mathrm{Si}_{\mathrm{c}}$ e $\mathrm{Si}_{\mathrm{d}}$ per sorgenti carsiche di diversa litologia. 
Tab. 2 - Comparison of the coeffcients of variation for the springs Pellumbas and Iskrec with Rock Spring and Thomson Spring (Shuster and White 1971; Jacobson and Langmuir 1974). Tab. 2 - Confronto del coefficiente di variazione delle sorgenti Pellumbas e Iskrec con le sorgenti Rock e Thomson (Shuster and White 1971; Jacobson and Langmuir 1974).

\begin{tabular}{|l|c|c|c|c|}
\hline \multicolumn{1}{|c|}{ Variable } & $\begin{array}{c}\text { Rock Spring } \\
\text { Conduit type }\end{array}$ & $\begin{array}{c}\text { Thomson Spring } \\
\text { Diffusive type }\end{array}$ & Pellumbas & Iskrec \\
\hline Nr of measurements & & & 11 & 30 \\
\hline Temperature & 26.9 & 1.4 & 4.2 & 10.27 \\
\hline Total hardness & 26.0 & 4.8 & 13.4 & 6.34 \\
\hline $\mathrm{EC}-\mu$ & 23.0 & 6.2 & 7.2 & - \\
\hline $\mathrm{Ca}^{+}$ & 25.5 & 6.4 & 12.6 & 11.7 \\
\hline $\mathrm{Mg}^{+}$ & 27.6 & 2.0 & 23.5 & 30.0 \\
\hline $\mathrm{SO}_{4}^{-}$ & 12.7 & 17.8 & 20.7 & 43.7 \\
\hline $\mathrm{pH}^{-}$ & 1.7 & 0.6 & - & 1.6 \\
\hline $\mathrm{Discharge}$ & 175.0 & 26.3 & - & 94.2 \\
\hline $\mathrm{Si}_{\mathrm{c}}$ & 18.7 & 16.1 & - & 35.5 \\
\hline
\end{tabular}

\section{Physical aspects of karst aquifers by spring's chemistry}

There are at least two end member types of the groundwater flow in karst aquifers: conduit flow and diffuse flow (White 1969). The variation of the physical and chemical characteristics of the springs could be used to characterize physical behaviour of the karst aquifers (Shuster and White 1971; Jacobson and Langmuir 1974), but this could be done estimating also the limitations (Scanlon and Thrailkill 1987). Most valuable parameters to be applied for this purpose seem to be the temperature, the hardness and electrical conductivity.

The coefficient of variation - $\mathrm{CV} \%$, which is 100 times the standard deviation divided by the mean, may describe the changes in water chemistry (Shuster and White 1971). The coefficients of variation result grater for the conduit flow springs and least for diffuse flow springs. The $\mathrm{CV}$ values of coefficients of variation of some physical and chemical parameters (Table 2) suggest that the Pellumbas is a diffuse flow spring and the Iskrec Spring is of conduit type. The field evaluation of the surface karst phenomenon supports the same conclusion; while the Dajti karst massive recharging the Pellumbas spring is very poor in surface karst forms, the karst basin recharging the Iskrec spring is very reach in such forms (Eftimi and Benderev 2007). This method is successfully applied also for identification of physical behaviour of the karst aquifers in Jordan (Abboud 2016).

\section{Recharge of the Poçemi springs by the Vjosa River}

The construction of a dam $110 \mathrm{~m}$ high was proposed on the Vjosa River, in south-central Albania, to produce electricity. The future lake would be developed east to the dam site widely contacting with high karstified rocks. A group of springs, named Poçemi, issuing from the Kremenara karstic massive (Dhame 1987), is located approximately $1.5 \mathrm{~km}$ north to the proposed dam site, (Fig. 4). Poçemi springs issuing at elevation $41 \mathrm{~m}$ above sea level and their average discharge is $1.7 \mathrm{~m}^{3} / \mathrm{s}$. The annual karst groundwater resources of the Kremenara basin result into $14.7 * 106$, (corresponding to $0.46 \mathrm{~m}^{3} / \mathrm{s}$ ), equal to $27 \%$ of the total discharge of the Poçemi springs. This result supports the hypothesis about the existence of another

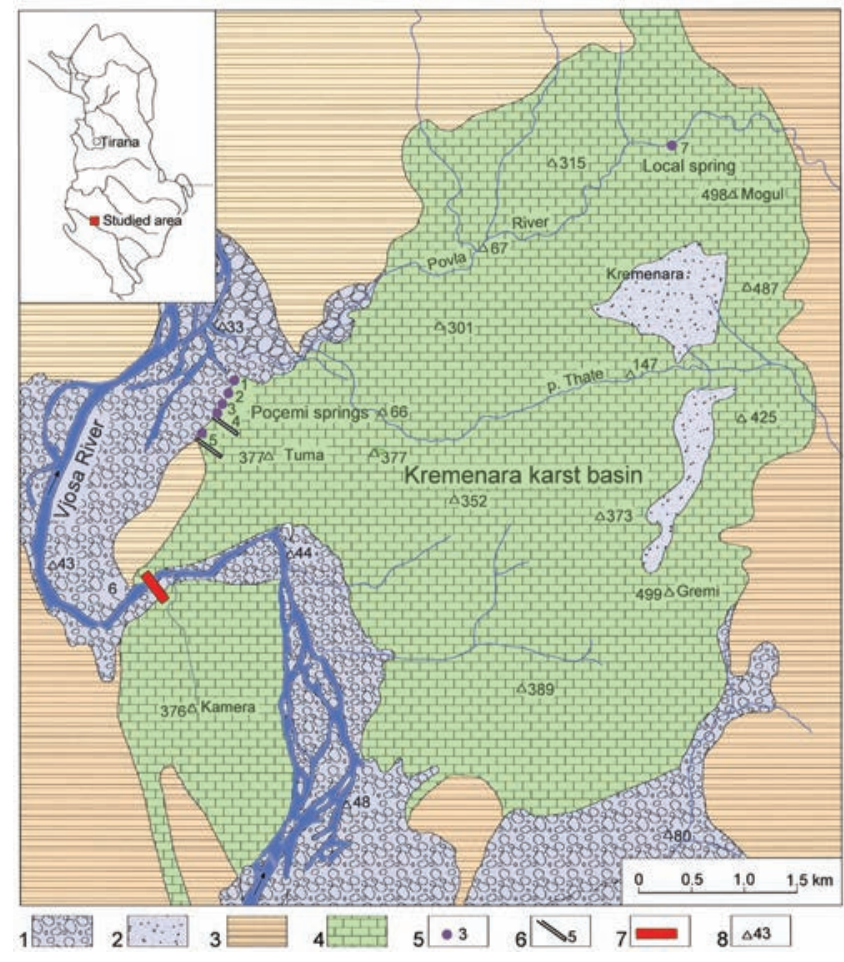

Fig. 4 - Geological Map of Kremenara karst basin and location of sampling points. 1. Gravel; 2. Clay (terra rossa); 3. Mainly siltstone; 4. Limestone; 5. Spring; 6. Gallery with water; 7. Project dam site; 8. Elevation in $m$ a.s.l.

Fig. 4 - Carta Geologica del bacino carsico di Kremenara e ubicazione dei punti di campionamento: 1) Ghiaia; 2) Argilla (terra rossa); 3) Silititi; 4) Calcari; 5) Sorgenti; 6) Galleria con acqua; 7) Zona di progetto della diga; 8) Quote sul livello del mare.

additional recharge source for the Poçemi springs.

The investigation was based on the assumption that isotopic contents of local precipitation, Poçemi springs and of Vjosa River are different. Seven sampling points were chosen (Fig. 4): five issues of Poçemi spring ( $\mathrm{Nr} 1$ to 5); Vjosa River ( $\mathrm{Nr}$ 6) and a spring of local recharge issuing at elevation about $40 \mathrm{~m}$ above Vjosa Rivera level ( $\mathrm{Nr} 7$ ). Sampling campaign organised on monthly bases collection lasted one year. Temperatures, electric conductivity and $\mathrm{pH}$ of the sampled surface or groundwater 
Tab. 3 - Mean values of some selected chemical data and of oxygen-18 of the water sampling points T - temperature; $C$ - conductivity; $\sigma$ - standard deviation; VR - Vjosa River; LS - Local spring.

Tab. 3 - Valori medi di alcuni dati chimici selezionati e dell'Ossigeno 18 dei punti d'acqua campionata. T - temperatura; C - conduttività; $\sigma$ - deviazione standard; VR - Fiume Vjosa; LS - Sorgenti locali.

\begin{tabular}{|c|c|c|c|c|c|c|c|c|c|}
\hline \multirow{2}{*}{ Sampling Points } & \multirow{2}{*}{$\begin{array}{c}\mathrm{Nr} \text { of chemical } \\
\text { analyses }\end{array}$} & \multirow{2}{*}{$\mathrm{T}^{\circ} \mathrm{C}$} & \multirow{2}{*}{$\mathrm{C} \mu \mathrm{S} / \mathrm{cm}$} & \multicolumn{2}{|c|}{$\mathrm{Cl}$} & \multicolumn{2}{|c|}{$\mathrm{SO}_{4}$} & \multirow{2}{*}{$\begin{array}{c}\mathrm{Nr} \text { of isotope } \\
\text { analyses }\end{array}$} & \multirow{2}{*}{$\begin{array}{l}\delta^{18} \mathrm{O} \\
(\% \circ)\end{array}$} \\
\hline & & & & $\mathrm{mg} / 1$ & $\mathrm{meq} / \mathrm{l}$ & $\mathrm{mg} / \mathrm{l}$ & $\mathrm{meq} / 1$ & & \\
\hline $\begin{array}{c}\text { Poçemi Springs } \\
\sigma\end{array}$ & 54 & 13.8 & $\begin{array}{l}455 \\
5.9\end{array}$ & $\begin{array}{l}22.7 \\
1.54\end{array}$ & $\begin{array}{l}0.64 \\
0.04\end{array}$ & $\begin{array}{l}53.8 \\
4.94\end{array}$ & $\begin{array}{l}1.12 \\
0.10\end{array}$ & 160 & $\begin{array}{l}-7.85 \\
0.08\end{array}$ \\
\hline $\begin{array}{c}\text { Vjosa River } \\
\sigma \\
\end{array}$ & 11 & 18.8 & $\begin{array}{l}446 \\
38.2 \\
\end{array}$ & $\begin{array}{l}26.6 \\
5.50\end{array}$ & $\begin{array}{l}0.75 \\
0.15\end{array}$ & $\begin{array}{l}64.8 \\
16.89\end{array}$ & $\begin{array}{l}1.35 \\
0.35\end{array}$ & 32 & $\begin{array}{c}-8.20 \\
0.28\end{array}$ \\
\hline $\begin{array}{l}\text { Local Spring } \\
\qquad \sigma\end{array}$ & 10 & 16.5 & $\begin{array}{l}645 \\
8.7\end{array}$ & $\begin{array}{l}22.7 \\
2.06\end{array}$ & $\begin{array}{l}0.64 \\
0.06\end{array}$ & $\begin{array}{l}27.1 \\
4.72\end{array}$ & $\begin{array}{l}0.56 \\
0.10\end{array}$ & 28 & $\begin{array}{l}-6.55 \\
0.07\end{array}$ \\
\hline
\end{tabular}

were measured in the field. The samples were analyzed for the major ions in the laboratory of the Hydrogeological Service of Tirana and for Oxigen-18 and Deuterium in the Laboratory of Isotope Section of IAEA (Table 3).

Fig. 5 shows the seasonal variations in the oxigen-18 content of the Poçemi springs, the Vjosa River and the spring of local recharge. The oxygen-18 content of the Poçemi springs is similar and homogenous at $-7.85 \%$ vs SMOW, which indicates a well mixed aquifer. The average oxygen- 18 value of the Vjosa River is $-8.22 \%$ vs SMOW, and that of the local spring is $-6.55 \%$. The difference of mean oxygen-18 content indicates that the observation points have different recharge elevation.

Particularly indicative are the average chemical analyses of the Poçemi springs, of the Vjosa River and of the local spring are presented on a Schœeller diagram (Fig. 2). The Vjosa River and the Poçemi springs have similar chemical composition, whereas the chemical composition of the locally recharged spring is different. This fact suggests that at big proportion the Poçemi springs are recharged by the Vjosa River. The same is concluded also from the graphics showing the relation between $\delta^{18} \mathrm{O}$ and $\mathrm{SO}_{4}$ contents and of the water conductivity (Fig.7 and 8). On both graphics the Pocemi springs stay on the mixing line of the Vjosa River with the local spring which represents the Kremenara karst water.

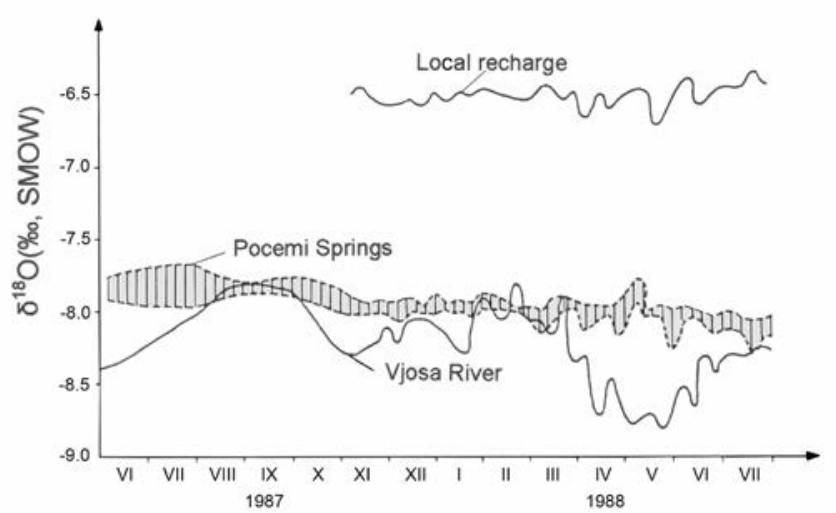

Fig. 5 - Variation in oxygen-18 content of the Vjosa River, Poçemi springs and a spring of local origin.

Fig. 5 - Variazione in Ossigeno-18 del Fiume Vjosa, della sorgente Poçemi e di una sorgente di origine locale.

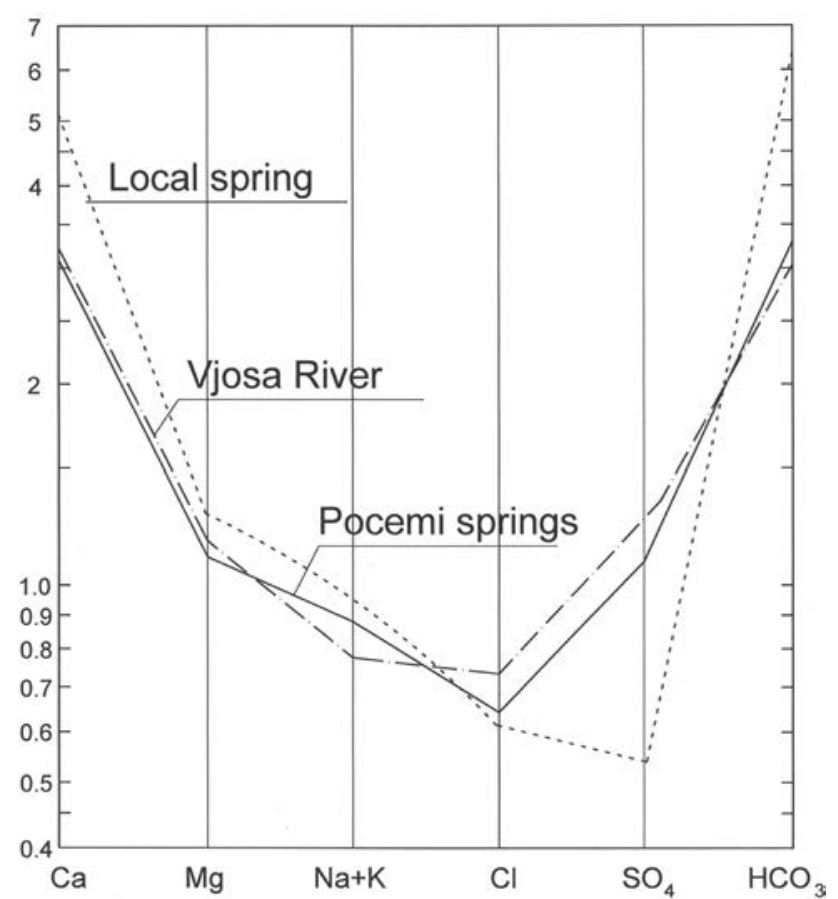

Fig. 6 -Scheeller diagram of the mean chemical composition of the Poçemi springs, of the Vjosa River and of the spring with local recharge. The similarity of the chemical composition of two different waters is in general considered as an indication of their possible similar origin (Mazor 1985).

Fig. 6 - Diagramma di Schœeller della composizione chimica media della sorgente Poçemi, del Fiume Vjosa e di una sorgente locale. La somiglianza della composizione chimica delle due diverse acque è in generale considerata come un indicatore di una loro simile origine (Mazor 1985).

Similar is also the relation of the conductivity with the $\delta^{18} \mathrm{O}(\%)$. The recharge area of the Vjosa River is where the River (or the riverbed gravelly deposits) come in contact with the limestone formations of Kremenara karst massive (Fig. 4). Based on simple two-component mixing analyses, the contribution of Poçemi spring recharge sources is estimated (Table 4).

The results of the estimation using isotopic content (Akiti et al. 1989) and $\mathrm{SO}_{4}$ concentration stay in a very good harmony (Table 4), and also fit very well with the results provided by the balance calculations (Eftimi and Dhame 1990). 


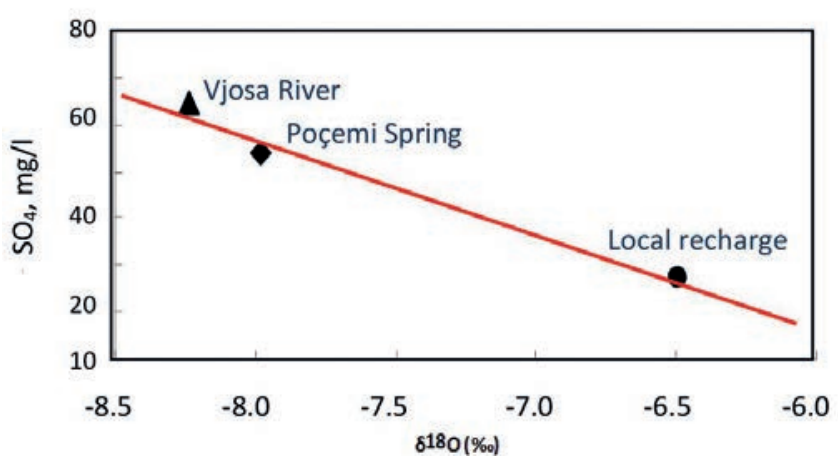

Fig. 7 - Relationship between $\delta^{18} O$ and sulphate concentration in Vjosa River, Poçemi springs and a local spring.

Fig. 7 - Relazione tra $\delta^{18} \mathrm{O}$ e la concentrazione dei solfati nel Fiume Vjosa, nella sorgente Poçemi e in una sorgente locale.

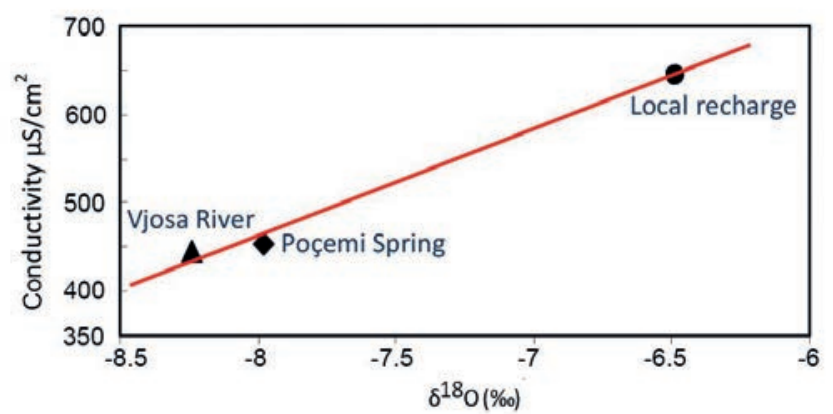

Fig. 8 - Relationship between $\delta^{18} O$ and electrical conductivity in Vjosa River, Poşemi springs and a local spring.

Fig. 8 - Relazione tra $\delta^{18} \mathrm{O}$ e la conducibilità elettrica nel Fiume Vjosa, nella sorgente Poçemi e in una sorgente locale.

Tab. 4 - Estimated recharge sources of Poşemi springs.

Tab. 4 - Fonti di ricarica stimate per le sorgenti Poçemi.

\begin{tabular}{|l|c|c|}
\hline \multicolumn{1}{|c|}{ Method } & $\begin{array}{c}\text { Kremenara karst massif } \\
\%\end{array}$ & $\begin{array}{c}\text { Seepage of Vjosa River } \\
\%\end{array}$ \\
\hline Isotope & 20.0 & 80.0 \\
\hline Hydrochemical & 23.0 & 77.0 \\
\hline Balance & 27.0 & 73.0 \\
\hline
\end{tabular}

\section{Recharge of Ohrid Lake by Prespa lake}

The Small and Big Prespa Lake and the Ohrid Lake waters are shared by Albania, FYR of Macedonia and Greece and constitute a common hydraulic system (Fig. 9, see side page). The Prespa Lake elevation is $850 \mathrm{~m}$ asl while the Ohrid Lake is at $695 \mathrm{~m}$ asl. Their respective surfaces are $274 \mathrm{~km}^{2}$ and 348 $\mathrm{km}^{2}$. Both lakes are separated by the Mali Thate - Galichica karst massif highest peak, $2287 \mathrm{~m}$ a.s.l. Big graben structures, that of Prespa Lake on the east, and that of Ohrid Lake on the west delimit both sides of the Mali Thate karst massif, geologically representing a horst. On the Ohrid lakeside, in the Albanian-FYROM borderland the big karst springs of St. Naum and Tushemisht are situated, which in total discharge about $255 * 106 \mathrm{~m}^{3} /$ year $\left(8.1 \mathrm{~m}^{3} / \mathrm{s}\right)$. Additional quantities of water drain into the lake as sub-lacustrine springs. In Zaver swallow hole located in Prespa Lake shore, the intensive loss of the lake water into the karst rocks could be observed in case of very low lake level (Fig. 10). Cvijic (1906) was the first to formulate the hypothesis that Prespa Lake recharges the karst springs of St.Naum and Tushemisht.

The altitude effect of stable isotopes in meteoric waters (Bradley at al. 1972) was used to identify waters coming from different potential groundwater recharge sources of the study area. The local precipitation on the karst massif and Prespa Lake water is examined as some recharge potential source to Mali Thate - Galichica karst groundwater.

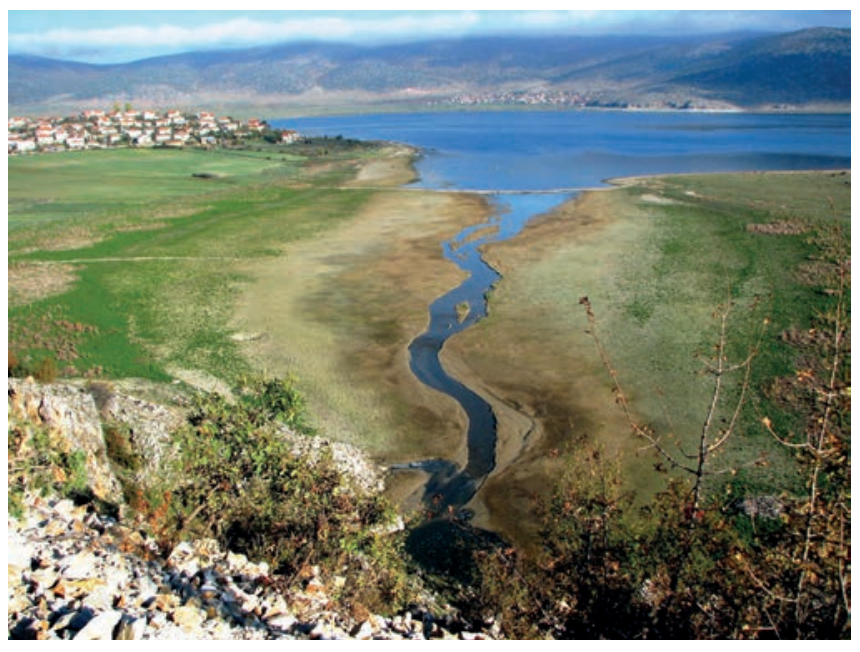

Fig. 10 - Zaver swallow bole in Prespa lakeside, during the extraordinary low lake level of the year 2004.

Fig. 10 - L'inghiottitoio carsico Zaver sul bordo del Lago Prespa, durante il livello straordinariamente basso registratosi nel 2004.

Fig. 11 shows the correlation between mean $\delta^{18} \mathrm{O}$ and $\delta \mathrm{D}$ values based on the results of isotope analyses from sampling points on the territory of Albania (Eftimi and Zoto 1997; Eftimi et al. 2002) and of FYR of Macedonia (Anovski at al. 1991). The slope of the Local Meteoric Water Line (LMWL) is 8 , which is the same as that of the Global Meteoric Water Line (GMWL), but the deuterium excess $d$ is 14 instead of 10 of the GMWL. Such "anomalous" values of intercept are characteristic for Eastern Mediterranean countries (Gat \& Dansgaard 1970; Leontiadis et al. 1997).

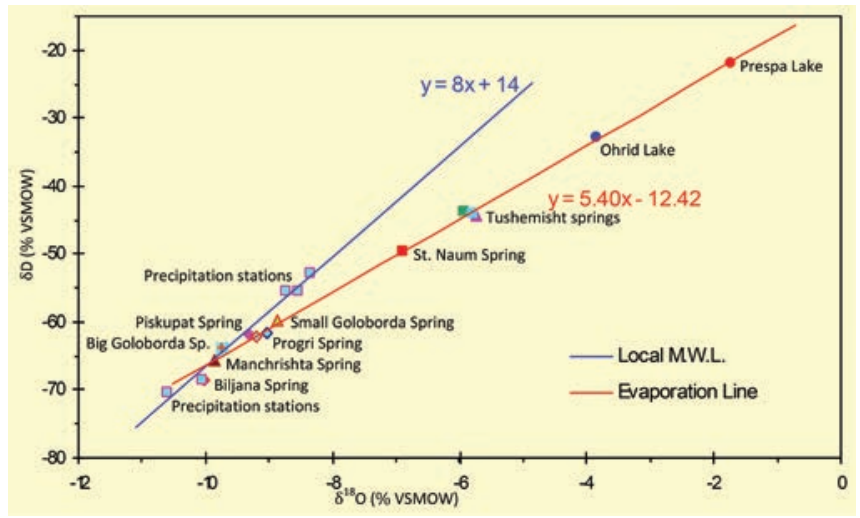

Fig. $11-\delta^{18} O-\delta D$ plot of waters from the area of the Prespa and Obrid lakes. Fig. 11 - Grafico $\delta^{18} \mathrm{O}-\delta \mathrm{D}$ delle acque dall'area dei laghi Prespa e Ohrid. 


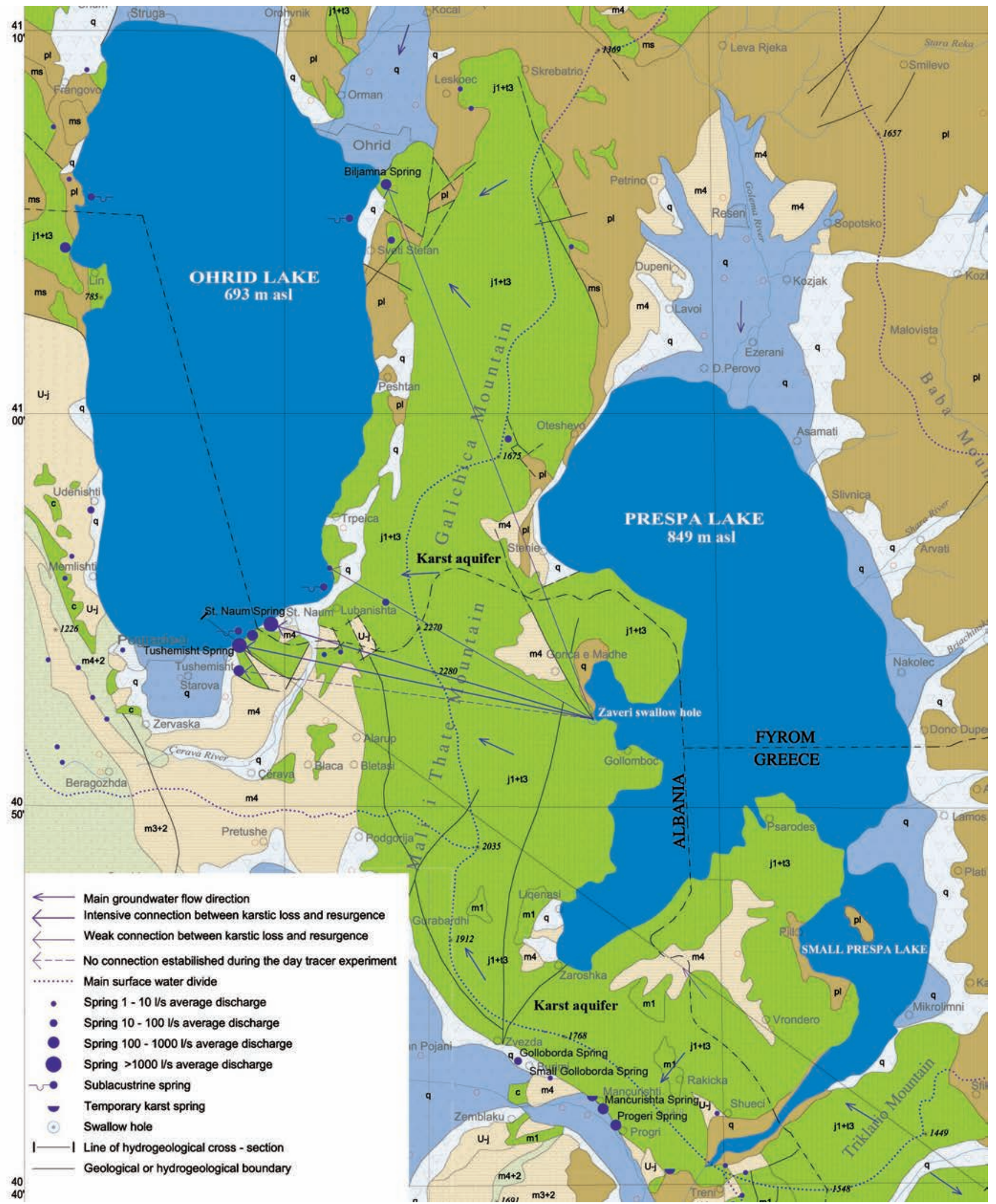

Fig. 9 - Hydrogeological Map of the area of the lakes Prespa and Ohrid (compiled by R. Eftimi).

Fig. 9 - Carta idrogeologica dell'area dei laghi Prespa and Ohrid (realizzata da R. Eftimi). 
The slope of LMWL for investigated lakes and springs is 5.4, which indicates that the water from the sampled points has been influenced by excessive evaporation relative to the input, which in the present case, is caused by the intensive evaporation of the Prespa Lake. The mixing at different proportions, of the precipitations infiltrated into the karst massif, and of the Prespa Lake water, is responsible for the isotopic composition of the springs falling in the evaporation line. The mixing end- members are the Prespa Lake (indexes $\delta^{18} \mathrm{O}=-1.72 \%$ and $\delta \mathrm{D}=-21.84 \%$ ), and the infiltrated in the karst massif precipitation represented by the point of interception of both lines in Fig. 11 (indexes $\delta^{18} \mathrm{O}=-10.20 \%$ and $\delta \mathrm{D}=-67.00 \%$ ). Environmental stable isotopes ${ }^{2} \mathrm{H}$ and ${ }^{18} \mathrm{O}$ demonstrate that the Prespa Lake recharge contribution is bigger in Tushemisht Spring than in St. Naum Spring (Table 5).

Applying the two-component mixing analysis was find that Tushemisht Spring is recharged at $53 \%\left(1.3 \mathrm{~m}^{3} / \mathrm{s}\right)$ by the Prespa Lake and at $47 \%\left(1.2 \mathrm{~m}^{3} / \mathrm{s}\right)$ by the precipitations infiltrated in the Mali Thate-Galichca karst massif (Eftimi and Zoto 1997). The contribution of Prespa Lake to the recharge of the St. Naun Spring is smaller; according to Anovski at al. (1991), it makes about $38 \%$ of the mean discharge of this spring. The total contribution of Prespa Lake to Tushemisht and St. Naun Springs is about $3.65 \mathrm{~m}^{3} / \mathrm{s}\left(115^{*} 10^{6} \mathrm{~m}^{3} /\right.$ year $)$, and the contribution of the precipitation is about $4.45 \mathrm{~m}^{3} / \mathrm{s}\left(140.3^{*} 10^{6}\right.$ $\mathrm{m}^{3} /$ year).

Tab. 5 - The contribution of Prespa Lake to the recharge of karst springs at Obrid lakeside (PL-Prespa Lake water, IP-Infiltrated precipitation in the karst massif).

Tab. 5 - Il contributo del lago Prespa alla ricarica delle sorgenti carsiche dal lato del lago Ohrid (PL - Acqua del Lago Prespa, IP- Infiltrazione delle precipitazioni nel massiccio carsico).

\begin{tabular}{|l|c|c|c|c|c|c|}
\hline Spring & \multicolumn{2}{|l|}{$\begin{array}{l}\text { Anovski et } \\
\text { al. 1991 }\end{array}$} & \multicolumn{2}{l|}{$\begin{array}{l}\text { Eftimi et } \\
\text { al. 1997 }\end{array}$} & \multicolumn{2}{l|}{$\begin{array}{l}\text { IAEA, Regional Project } \\
\text { RER/8/008,2003 }\end{array}$} \\
\hline & $\begin{array}{c}\text { PL } \\
(\%)\end{array}$ & $\begin{array}{c}\text { IP } \\
(\%)\end{array}$ & $\begin{array}{c}\text { PL } \\
(\%)\end{array}$ & $\begin{array}{c}\text { IP } \\
(\%)\end{array}$ & $\begin{array}{c}\text { PL } \\
(\%)\end{array}$ & $\begin{array}{c}\text { IP } \\
(\%)\end{array}$ \\
\hline St. Naum & 42 & 58 & & & 37 & 63 \\
\hline Tushemisht & & & 52 & 48 & 54 & 46 \\
\hline
\end{tabular}

The results of an artificial tracer experiment supported by IAEA showed a very complex groundwater circulation system in the Mali Thate - Galichica karst massif. Big differences of the measured maximum flow velocities (from $233 \mathrm{~m} / \mathrm{h}$ to $3200 \mathrm{~m} / \mathrm{h}$ ) indicate the presence of differently developed karst conduits at small-scale distances (Amataj et al. 2005).

\section{Identification of recharge sources of the Bistrica karst spring}

The goal of this research was to investigate the mechanism of recharge of the Mali Gjere Mountain karst massif feeding the largest Albania's spring, Bistrica. Mali Gjere Mountain karst massif is located in the south-eastern part of Albania, on the border with Greece. The total surface of the karst massif is $440 \mathrm{~km}^{2}$, mostly located in Albanian territory (about 400 $\mathrm{km}^{2}$ ). The highest peaks of Gjere Mountain are 1798 a.s.l. and the mean elevation is about $900 \mathrm{~m}$ a.s.l. The mountain crest is a natural surface water divide between the Drinos River located on the east, and Bistrica River basin located on the west. Gjere Mountain is an anticline (Fig. 12, 13) consisting of a Mesozoic carbonate sequence overthrown to Perm-Triassic gypsum and clay deposits, surrounded by Palaeogene and Neogene flysch formations. Only in the central-western side of the Gjere Mountain structure, from Jergucat village on the south to Dervician village on the north (distance $6.5 \mathrm{~km}$ ) the flysch formation is missing and the carbonate rocks contact the thick (over $100 \mathrm{~m}$ ) gravelly aquifer of Drinos valley.

Using the methods described by Turc (1954) and Kessler (1967) the effective infiltration of the mean annual precipitation recharge of Mali Gjere massif karst groundwater is estimated to equal to about $1175 \mathrm{~mm} /$ year $\left(5.17 * 10^{8} \mathrm{~m}^{3} /\right.$ year, or 16.4 $\mathrm{m}^{3} / \mathrm{s}$ ). The evapotranspiration resulted to be about $573 \mathrm{~mm} /$ year $\left(2.25 * 10^{8} \mathrm{~m}^{3} /\right.$ year, or $\left.8.0 \mathrm{~m}^{3} / \mathrm{s}\right)$ and the surface runoff is $175 \mathrm{~mm}\left(0.77 * 10^{8} \mathrm{~m}^{3} /\right.$ year, or $\left.2.44 \mathrm{~m}^{3} / \mathrm{s}\right)$. Most of the karst water resources of the Mali Gjere massif discharge in its western side, where Bistrica spring with a mean discharge of $18.4 \mathrm{~m}^{3} / \mathrm{s}$ issues, as well as some other springs, each having a mean discharge of about $100 \mathrm{l} / \mathrm{s}$.

The largest spring on the eastern side of the massif is the temporary spring Viroi, flowing only about 8 to 9 months a year, and having maximal discharge of about $40 \mathrm{~m}^{3} / \mathrm{s}$. The third important spring is Lista, mean discharge of $1.7 \mathrm{~m}^{3} / \mathrm{s}$ is situated on Greek territory. The total discharge of the springs of Mali Gjere Mountain karst massif is estimated at about $7.42 * 10^{8} \mathrm{~m}^{3} /$ year, $\left(23.6 \mathrm{~m}^{3} / \mathrm{s}\right)$. As seen, the total discharge of the springs of the massif is about $2.26 * 108 \mathrm{~m}^{3} /$ year $\left(7.2 \mathrm{~m}^{3} / \mathrm{s}\right)$, equal to about $30 \%$ larger than the calculated mean efficient precipitation infiltration into the massif (Eftimi at al 2007; Eftimi 2009). Environmental isotope techniques combined with the hydrological and hydrochemical methods were used to verify the partial replenishment of the karst water resources of Mali Gjere karst massif by the Drinos River basin gravelly aquifer. This is facilitated by the good hydraulic connection between both aquifers, and by the natural groundwater slope to the Blue Eye Spring, (Fig. 13).

Sample collection began in January 1988 and continued until December 1999, and some sporadic sampling was done

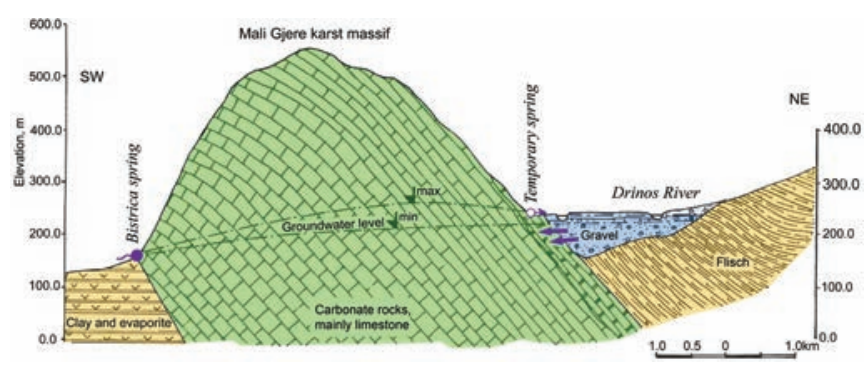

Fig. 13 - Hydrogeological cross-section of Gjere Mountain.

Fig. 13 - Sezione idrogeologica del Monte Gjere. 


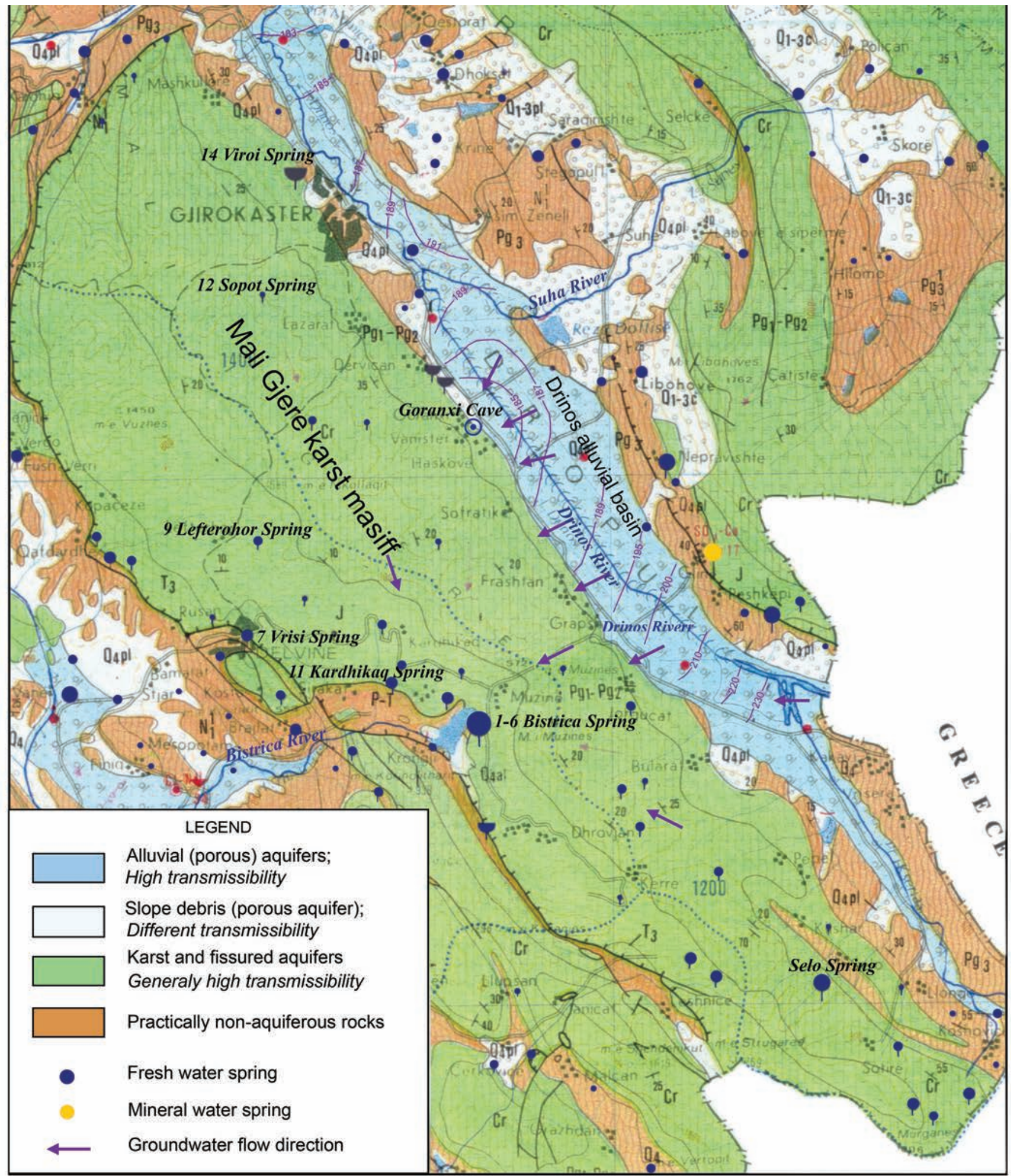

Fig. 12 - Hydrogeological Map of Gjere Mountain karst massif area and the sampling points (Eftimi at al. 1985).

Fig. 12 - Carta idrogeologica dell'area del massiccio carsico del Monte Gjere e punti di campionamento (Eftimi at al. 1985). 
Tab. 6 - Mean isotopic composition of water samples of Gjere Mountain karst massif. No-order number, $S L$ - sampling location, $E$ - elevation, $M D-$ mean discharge, Nr-number of the measurements, $D E$ - deuterium excess, $T$ - temperature, $E C$ - electric conductivity.

Tab. 6 - Composizione isotopica media dei campioni di acqua del massiccio carsico del Monte Gjere. No - numero d'ordine; SL - punto di campionamento; E quota; MD - portata media; $\mathrm{Nr}$ - numero di misure; DE - deuterio in eccesso; T - temperatura; EC - conducibilità elettrica.

\begin{tabular}{|c|c|c|c|c|c|c|c|c|c|c|}
\hline No & SL & $\begin{array}{l}\mathrm{E} \\
\mathrm{m}\end{array}$ & $\begin{array}{c}\text { MD } \\
1 / s\end{array}$ & $\mathrm{Nr}$ & $\begin{array}{l}\delta^{18} \mathrm{O} \\
{[\% \circ]}\end{array}$ & $\begin{array}{l}\delta \mathrm{D} \\
{[\% \circ]}\end{array}$ & $\begin{array}{l}\mathrm{DE} \\
{[\% \circ]}\end{array}$ & $\begin{array}{l}\mathrm{T} \\
{ }^{\circ} \mathrm{C}\end{array}$ & $\begin{array}{c}\mathrm{EC} \\
\mu / \mathrm{cm}\end{array}$ & $\begin{array}{l}\mathrm{SO}_{4}^{--} \\
\mathrm{mg} / 1\end{array}$ \\
\hline $1-6$ & Bistrica spring & 152 & 18000 & 34 & $-7.58 \pm 0.16$ & $-43.88 \pm 2.4$ & +16.76 & 12.4 & 585 & 135.0 \\
\hline 7 & Vrisi spring & 177 & 70 & 8 & $-6.66 \pm 0.13$ & $-35.10 \pm 2.0$ & +18.80 & 14.5 & 430 & 32.2 \\
\hline 9 & $\begin{array}{l}\text { Lefterohor } \\
\text { spring }\end{array}$ & 590 & 0.4 & 6 & $-6.95 \pm 0.18$ & $-37.00 \pm 2.0$ & +18.60 & 12.4 & 337 & 9.9 \\
\hline 11 & $\begin{array}{l}\text { Kardhikaq } \\
\text { spring }\end{array}$ & 185 & 90 & 8 & $-6.71 \pm 0.16$ & $-36.40 \pm 1.6$ & +17.28 & 14.3 & 567 & 121.4 \\
\hline 12 & Sopot spring & 1000 & 1.5 & 5 & $-8.26 \pm 0.12$ & $-47.20 \pm 0.6$ & +18.88 & 8.4 & 189 & 18.1 \\
\hline 14 & Viroi spring & 196 & $0-40000$ & 5 & $-7.99 \pm 0.19$ & $-44.90 \pm 2.9$ & +19.02 & 11.2 & 371 & 47.0 \\
\hline 15 & $\begin{array}{l}\text { Jergucat, } \\
\text { borehole }\end{array}$ & 198 & - & 3 & $-6.80 \pm 0.13$ & $-42.20 \pm 1.8$ & +12.20 & 12.8 & 786 & 258.0 \\
\hline 16 & $\begin{array}{l}\text { Drinos River, } \\
\text { Bularat }\end{array}$ & 197 & - & 3 & $-6.80 \pm 0.13$ & $-42.00 \pm 1.7$ & +12.40 & 13.8 & 950 & 385.0 \\
\hline 17 & $\begin{array}{l}\text { Lista spring, } \\
\text { Greece }\end{array}$ & - & 1700 & 10 & - & - & - & 12.4 & 270 & 11.0 \\
\hline
\end{tabular}

during 1996. The sampling locations are shown in Figure 12 and the index values are presented on Table 6.

\section{Isotope data}

The isotopic composition of all the six outlets of Bistrica spring (nr1-6) is very similar and homogenous and the standard deviation of mean values for each outlet varies within $0.02-0.08$ for $\delta^{18} \mathrm{O}$ and within $0.6-1.1$ for $\delta \mathrm{D}$ values. The $\delta^{18} \mathrm{O}$ and $\delta \mathrm{D}$ values of Bistrica spring presented on Table 4 are the weighted values of six spring's outlets.

The correlation function between mean $\delta^{18} \mathrm{O}$ and $\delta \mathrm{D}$ values of sampled points and (Fig. 14) results in two equations (Eftimi 2009; Eftimi at al. 2007):

$$
\begin{aligned}
& \delta \mathrm{D}=7.29 \delta^{18} \mathrm{O}+13.18(\mathrm{r}=0.99) \\
& \delta \mathrm{D}=2.28 \delta^{18} \mathrm{O}-26.58(\mathrm{r}=0.99)
\end{aligned}
$$

Equation (1) could be considered a local meteoric water line and its slope is close to 8 of the GMWL. The deuterium excess is $+13 \%$ instead of $+10 \%$ of the global meteoric water line (Dansgard 1964) as Albania belongs to the east Mediterranean anomalous zone concerning the deuterium axis (Gat and Carmi 1970; Gat and Dansgaard 1970). Equation (2) describes a mixing line; the mixing of infiltrated into the karst massif precipitation and of the groundwater of Drinos valley gravelly aquifer is responsible for the isotope composition of the Bistrica spring. The very negative value of deuterium excess on equation (2) is related to the evaporation water line. Nevertheless must be mentioned that the number of analyses, particularly for the points 15 and 16 (Table 6) is small and could influence in the accuracy of the results.

The infiltrated precipitation into the karst massif is represented by the values of interception of both lines (Fig. 14), which practically coincides with the isotope composition of the Viroi temporary spring, nr $14, \delta^{18} \mathrm{O}=-$ $7.99 \%$ and $\delta \mathrm{D}=-44.90 \%$. The groundwater recharged by the Drinos River gravelly aquifer groundwater is affected by the relative $\delta \mathrm{D}$ and $\delta^{18} \mathrm{O}$ enrichment. It seems that the mean recharge area of the Drinos River catchment has lower elevation than that of the Gjere Mountain karst massif. The isotope composition of gravelly aquifer groundwater is represented by the Jergucat borehole $\delta^{18} \mathrm{O}=-6.80 \%$ and $\delta \mathrm{D}=-42.20 \%$. Based on simple two-component mixing analyses, the Drinos Valley gravely aquifer is estimated to contribute about $30 \%$ to the replenishment of the Bistrica spring. This is equal to $5.52 \mathrm{~m}^{3} / \mathrm{s}$ or $1.74 * 10^{8} \mathrm{~m}^{3} /$ year.

The data of two local springs are considered to define the altitude effect (Fig. 15), and to predict the Mra from the $\delta^{18} \mathrm{O}$ values of the springs based on the following equation (3):

$$
\operatorname{Mra}(\mathrm{m})=-312 \delta^{18} \mathrm{O}-1585
$$

The altitude effect as defined by equation (3) is $-0.32 \% \mathrm{o}$ in $\delta^{18} \mathrm{O}$-values per $100 \mathrm{~m}$, which is in accordance with the values determined in many other studies mentioned in the Introduction of this paper. Using the relation presented in Figure 15 the Mra of some big springs of the study area result as below: Bistrica - 800 m; Vrisi - 500 m; Kardhikaqi - 515 $\mathrm{m}$ and Viroi $915 \mathrm{~m}$. These data are in the accordance with the hydrogeological settings of the area; the recharge elevation of Bistrica is somewhat diminished as the result of the partial recharge by the effected by evaporation the Drinos river water.

\section{Hydrochemical data}

Figure 16 shows the areal distribution of the sulphate ion concentration in the gravelly aquifer of Drinos river valley. The mean sulphate concentration in the southern and central part of the Drinos River basin is about 200 to more than $350 \mathrm{mg} / \mathrm{l}$, 

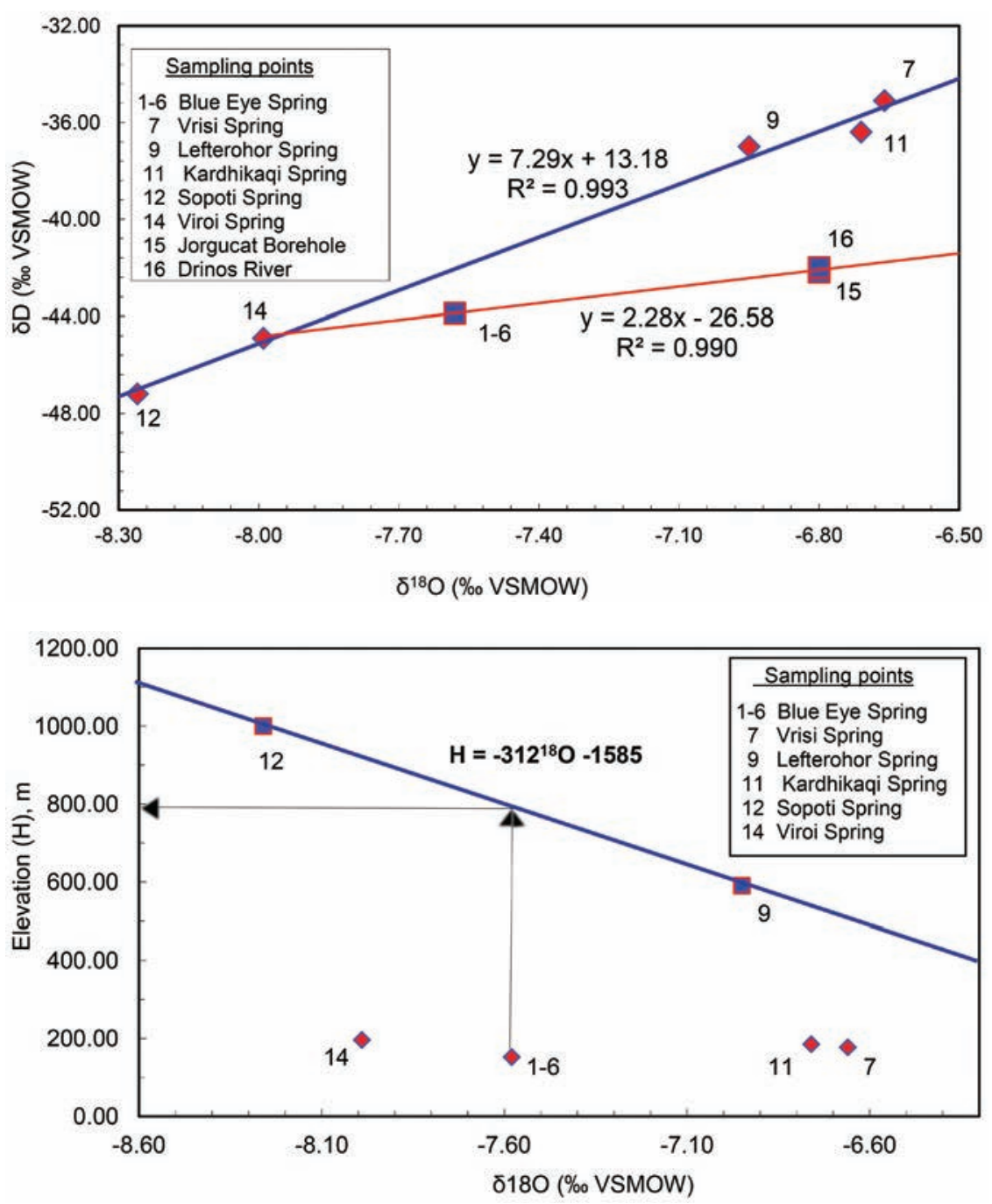

Fig. 14 - Relationship between $\delta^{18} O$ and $\delta D$ for waters of Gjere Mountain karst massif.

Fig. 14 - Relazione tra $\delta^{18} \mathrm{O}$ e $\delta \mathrm{D}$ er le acque del massiccio carsico del Monte Gjere.
Fig. $15-\delta^{18} \mathrm{O}$ versus altitude of springs.

Fig. $15-\delta^{18} \mathrm{O}$ a confronto con la quota delle sorgenti. but rapidly decreases in north direction. In the northernmost part of the valley the sulphate concentration become less than $50 \mathrm{mg} / \mathrm{l}$. The resulted relations of $\mathrm{SO}_{4}$ concentrations versus the $\delta^{18} \mathrm{O}$ concentrations proved to be very indicative for the identification of Bistrica springs recharge sources (Fig. 17). Bistrica spring (nr 1-6) and Kardhikaq spring (nr 11) are on the contact line between carbonate rocks and Upper Triassic clayey-gypsum deposits. They are characterized by similar sulphate concentration, but show of significant differences in isotope concentrations and temperature.

A careful examination of the Figure 17 enables us to understand the different origin of sulphate ions at both springs. The Bistrica spring lies on the mixing line, where endmembers are infiltrated precipitation into the karst massif, and the groundwater of Drinos valley gravelly basin. But the Kardhikaq spring lies far from the mixing line. This allows us to suppose that the high sulphate concentration of the Bistrica spring, is related to the high sulphate concentration in Drinos valley gravelly aquifer groundwater. As for Kardhikaq spring, which is recharged mainly by precipitation infiltration, the sulphate ion source could be the gypsum of Permian-Triassic deposits underlining the Triassic carbonate rocks.
The high sulphate concentration in the southern and central part of the valley is caused by the intensive infiltration of Drinos River water into the gravelly aquifer (Eftimi 2009). In the central part of the valley, in the sector between Jergucat and Sofratik villages, the enriched in sulphates gravelly aquifer groundwater seeps into Gjere Mountain karst massif (Fig. 12).

Sulphate ion is used as a neutral one to estimate the mixing proportions contributing to Bistrica spring using as endmembers the Viroi spring (point 14) for the karst massif groundwater, and the Jergucat borehole (nr 20) for the Drinos River gravelly aquifer. The sulphate concentrations of two mixing components used for the calculations are $47.0 \mathrm{mg} / \mathrm{l}$ for Viroi spring and $300 \mathrm{mg} / \mathrm{l}$ for the Drinos valley groundwater.

Based on simple two-component mixing analyses estimation was made that the contribution of the Drinos valley gravely aquifer consist about $35 \%$ of mean discharge from Bistrica spring. As seen in Table 7, the results obtained by the isotope and hydro-chemical environmental tracer methods, as well as those derived by the balance method are well comparable and stay in a good harmony. 


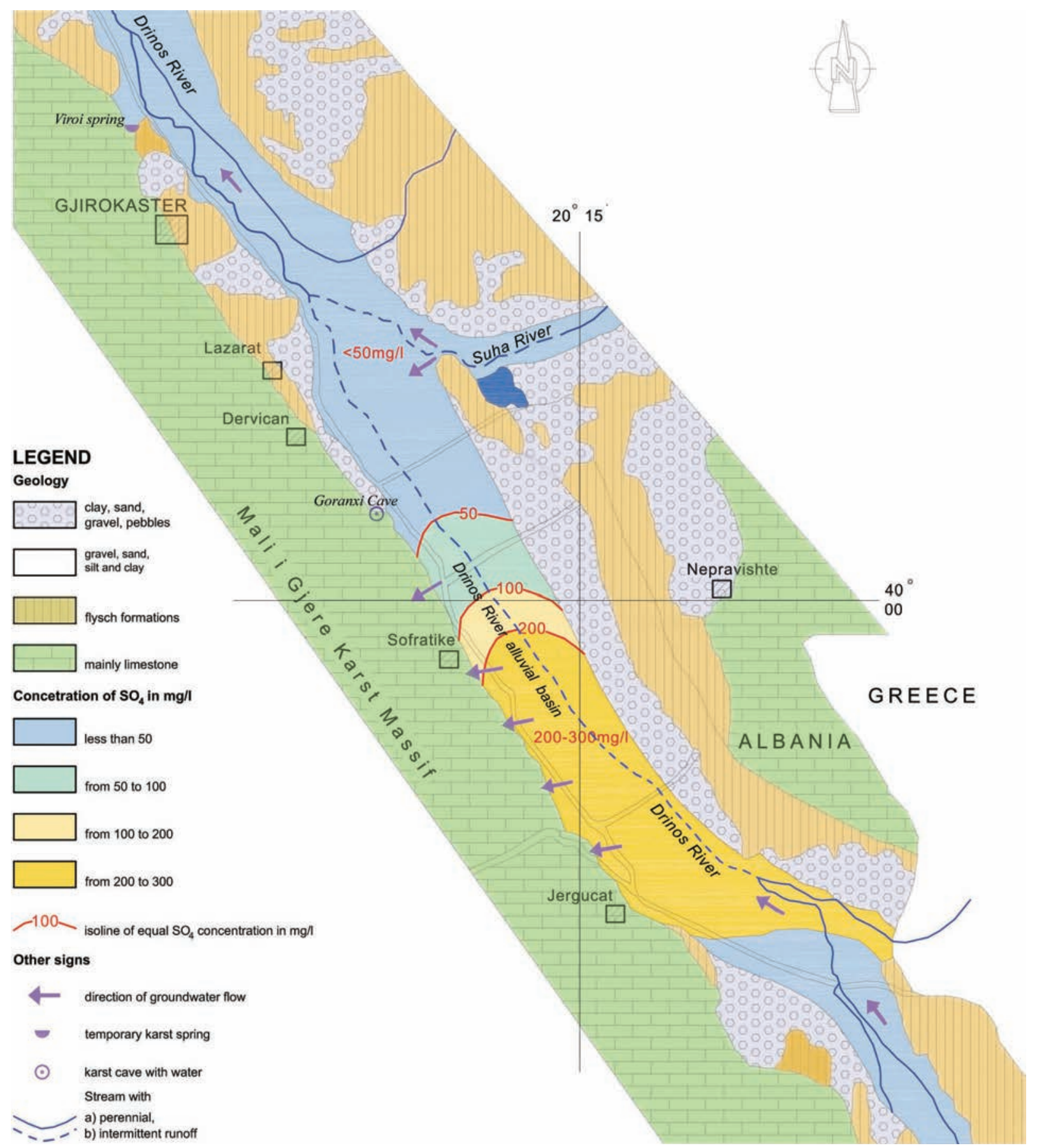

Fig. 16 - Concentration of $\mathrm{SO}_{4}$ ion in gravelly aquifer of Drinos River Valley.

Fig. 16 - Concentrazione dello ione $\mathrm{SO}_{4}$ nell'acquifero ghiaioso della Valle del Fiume Drinos.

Tab. 7 - Estimated recharge sources of Bistrica spring.

Tab. 7 - Aree di ricarica stimate della sorgente Bistrica.

\begin{tabular}{|l|c|c|c|c|}
\hline \multirow{2}{*}{ Method } & \multicolumn{3}{|c|}{ Recharge sources of the Bistrica spring } \\
\cline { 2 - 5 } & Infiltrated precipitation in Gjere Mountain & Seepage of Drinos valley groundwater in Gjere Mountain karst massif \\
\cline { 2 - 5 } & $\%$ & $\mathrm{~m}^{3} / \mathrm{s}$ & $\%$ & $\mathrm{~m}^{3} / \mathrm{s}$ \\
\hline Isotope & 70 & 12.88 & 30 & 5.52 \\
\hline Hydrochemical & 65 & 11.96 & 35 & 6.44 \\
\hline Balance & 61 & 11.23 & 39 & 7.17 \\
\hline
\end{tabular}




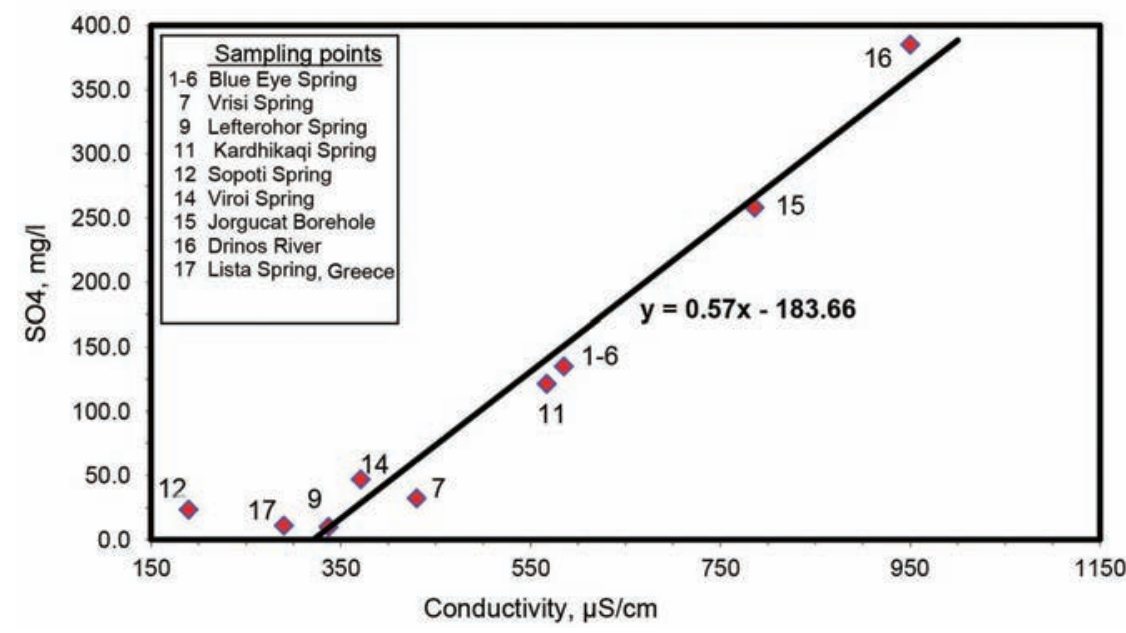

Fig. $17-\delta^{18} 0$ versus sulphate concentration for waters of Mali Gjere karst massif.

Fig. $17-\delta^{18} \mathrm{O}$ a confronto con la concentrazione del solfato delle acque del massiccio carsico del Mali Gjere.

\section{Conclusions}

The environmental isotope methods are successfully applied for the identification of recharge sources in some karst areas of Albania. The altitude effect on stabile isotope of oxygen and hydrogen isotopes and the modification of isotopic content of ground and surface water by mixing or evaporation, appear to be the key factors for solving the problem in concern. Combined application of environmental isotope and hydrochemical methods provide to be very useful evidence about the recharge sources of karst aquifers.

For characterising the lithology of karst rocks and the physical aspects of karst aquifers (type of groundwater flow) the combined use of some hydrochemical parameters like the water conductivity, total hardness, ionic ratios $\mathrm{rCa} / \mathrm{rMg}$, $\mathrm{rSO}_{4} / \mathrm{r} / \mathrm{mg}, \mathrm{CO}_{2}$ pressure and the indexes of calcite and $\left(\mathrm{Si}_{\mathrm{C}}\right)$ and of dolomite saturation $\left(\mathrm{Si}_{\mathrm{d}}\right)$, result very useful.

\section{REFERENCES}

Abboud I (2016) Describe and statistical Evaluation of Hydrochemical data of Karst phenomena in Jordan: Al-Dhaher Cave Karst https://www.researchgate.net/publicatio /274456473

Aggarwal PK, gat JR, Froehlich KFO (2005) Isotope in the Water Cycle, Springer.

Akiti T, Eftimi R, Dhame L, Zojer H, Zotel J (1989) Environmental isotope study of the interconnection between the Vjosa River and the Poçemi springs, Memoirs of 22nd Congress of IAH, Vol. XXII

Amataj S, Anovski T, Benishke R, Eftimi R, Gourcy L, Kola L, Leontiadis I, Micevski E, Stamos A, Zoto J, (2005) Tracer Methods Used to Verify the Hypothesis of Cvijic About the Groundwater Connection Between Prespa and Ohrid Lakes. Z. Stevanović \& P. Milanović (eds) Proceedings of the International conference and field seminars, Belgrade \& Kotor, Serbia \& Montenegro.

Anovski T, Andonovski B, Minceva B (1991) Study of the hydrologic relationship between Ohrid and Prespa lakes, Proceedings of IAEA International Symposium, IAEA-SM-319/62p, Vienna.

Appelo CAJ, Postma D (1999) Geochemistry, groundwater and pollution, A.A. Balkema.

Bakalowicz M (2005) Karst groundwater: a challenge for new resources. Hydrogeology Journal. 13:148-160

Bortolami GC, Ricci B, Susella GF, Zuppi GM (1979) Hydrogeochemistry of the Corsaglia Valley, Martime Alps. Piedmont, Italy. Journal of Hydrology, 44 (1-2)

Bradley M, Brown RM, Gonfiantini R, Payne BR, Prezewlocki K, Sauzay G, Yen CK, Yurtsever Y (1972) Nuclear techniques in groundwater hydrology, In: Groundwater Studies, Chap.10. UNESCO, Paris.

Cervi F, Corsini A, Doveri M, Mussi M, Ronchetti F, and Tazioli A (2015) Characterizing the recharge of fractured aquifers: A case study in a flysch rock mass of the Northern Appennines (Italy), Engineering Geology for Society and Territory - Vol. 3, Springer, 2015.

Clark ID, Fritz P (1997) Environmental Isotopes in Hydrogeology, Lewis Publishers. New York.

Cvijic J (1906) Fundamental of Geography and Geology of Macedonia and Serbia, Special Edition VIII+680, (in Serb-Croat), Belgrade.

Dansgard W (1964) Stable isotopes in precipitation. Tallus 16, 436468

Dhame L (1987) Karst and hydrotechnical constructions Ph. Dr. Thesis, Tirana.

Eftimi R (2009) Investigation of recharge sources of Bistrica karst spring, the biggest spring of Albania, by means of environmental hydrochemical and isotope tracers. Conference "Sustainability of Karst Environment-Dinaric Karst and other Karst Regions, Croatia. 
Eftimi R, (2005) About the hydrochemistry of of karst groundwater of Kruja - Dajti mountains, (in Albanain), Studime Gjeografike, nr. 110, Tirana.

Eftimi R, Benderev A (2007) Utilization of hydrochemical data for characterization of the karst system: example of Iskrets spring, Review of the Bulgarian Geological Society, vol. 68, part 1-3, Bulgaria.

Eftimi R, Amataj S, Zoto J (2007) Groundwater circulation in two transboundary carbonate aquifers of Albania; their vulnerability and protection. In: Groundwater Vulnerability Assessment and Mapping. Selected Papers on Hydrogeology, 11. Groundwater Vulnerability Assessment and Mapping, International Conference, Ustroń, Poland, 2004. A.J. Witkowski, A. Kowalczyk \& J. Vrba editors. Taylor \& Francis 2007, London.

Eftimi R, Dhame L (2006) Investigation about the recharge sources of Poçemi Springs in Albania by means of environmental hydrochemical tracers. Proceedings of XVIII ${ }^{\text {th }}$ Congress of the Carpathian-Balkan Geological Association. M. Sudar, M. Ercegovac \$ A. Grubić (eds.) Belgrade.

Eftimi R, (2005) Hydrochemical characterisation of some lithologicaly different karstr massifs of Albania. In: Water Resources \& Environmental Problems in karst, Proceedings of the International conference and field seminars 13-19 September, eds. Stevanovic Z and Milanović, Belgrade.

Eftimi R, Skende P, Zoto J (2002) Isotope Study of Connection of Ohrid and Prespa Lakes. Geologica Balcanica, 32. 1, Sofia.

Eftimi R, Zoto J (1996) Isotope study of the connection of Ohrid and Prespa lakes, In: International Symposium "Towards Integrated Conservation and Sustainable Development of Transboundry Macro and Micro Prespa Lakes", Symposium held in Korcha, Albania, 24-26 October 1997

Eftimi R, Tafilaj I, Bisha G, Sheganaku Xh (1985) Hydrogeological Map of Albania, scale 1:200.000, Tirana.

Gat JR Carmi J (1970) Evolution of isotopic composition of atmospheric waters in the Mediterranean Sea area. Journal of Geophysics, 75

Gat JR Dansgaard W (1970) Stable isotope survey of the freshwater occurrences in Israel and Jordan Rift Valley, Journal of Hydrology, 16

Glynn DG and Plumer LN (2005) Geochemistry and the understanding of ground-water systems, Hydrogeology Journal (2005) 13

IAEA (1981) Stable Isotope Hydrology; Deuterium and Oxygen-18 in the Water Cycle. Technical report series no.210, Vienna.

IAEA (1983) Guidebook on Nuclear Techniques in Hydrology, Technical report series no.91, Vienna.

IAEA (1989) Isotope Techniques in the study of the Hydrology of Fractured and Fissured Rocks, Vienna.

IAEA-IHLS (2004) Learning, Teaching and Applying Techniques in Hydrology, CD-ROM, In: IAEA. Vienna, Isotope Hydrology Section, IAEA, P.O. 100, A-1400 Wien.

Jacobson RL, Langmuir D (1974) Controls on the quality variations of some carbonate spring water. Journal of Hydrology, 23

Kattan Z (1997) Chemical and environmental study of precipitation in Syria. J. of Arid Environments, 35(4)
Kessler H (1967) Water balance investigations in the karstic regions of Hungary, In: Proc AIH-UNESCO, Symposium, In: Hydrology of Fractured rocks, 1965 Dubrovnik.

Langmuir D, (1971) The geochemistry of some carbonate ground waters of Central Pennsylvania, Geochem., Cosmocchim., Acta 35

Langmuir D, (1986) Physical and chemical characteristics of carbonate water, In: Guide to the hydrology of carbonate rocks, UNESCO.

Leontiadis IL, Vergis S, Christodoulou Th (1996) Isotope hydrology study of areas in Eastern Macedonia and Thrsce, Northern Greece. Journal of Hydrology, 182 (1-4)

Leontiadis IL, Smorniotis CH, Nikolau E, Georgiadis P (1997) Isotope hydrology study of the major areas of Paramythia and Korony, Epirus, Greece, In: Karst waters and environmental impacts. A.A. Balkema, Rotterdam.

Malik P (2007) Assessment of regional karstification degree and groundwater sensitivity to pollution using hydrograph analyses in the Velka Fatra Mountains, Slovakia. Environ. Geol. 51:707-711.

Malik P and Vojtková S (2008) Use of recession-curve analyses for estimation of karstification degree and its application in assessing overflow/underflow conditions in closely spaced karstic springs, Environ. Earth Sci. (2008) 54

Mazor EE (1985) Tracing groundwater by chemical, isotopic and physical parameters-Example: Schnzanach, Switzerland. Journal of Hydrology, 76

Mazor EE (1998) Chemical and isotopic Groundwater Hydrology - The Applied Approach. Marcel Dekker Inc.

Payne BR, Leontiadis LL, Dimitrulas I, Dounas A , Kallergis G, Morfis A (1978) A study of the Kalamos Spring in Greece with environmental isotopes. Water Resources Research Vol. 14, No. 4

Scanlon BR and Thrailkill J (1987) Chemical smililarities among physically distinct springs type in a karst terrain. Journal of Hydrology, 89, 259-279

Shuster ET, White WB (1971) Seasonal fluctuations in the chemistry of limestone springs: a possible mean for characterizing carbonate aquifers, Journal of Hydrology, 14

Tenu A, Davidescu FD (1983) Recherches isotopique sur les eaux souterraines des formations poreaua de la partie orientale de la Depression Pannonienne. (w): Isotope Hydrology, 1983, IAEA, Vienna.

Thrailkill J (1976) Carbonate equilibria in karst water, In: Karst hydrology and water resources. Proceed. Of US-Yugoslavian Symp. Dubrovnik.

Thrailkill L (1977) Relative solubility of limestone and dolomite In: Tolson I. S. \& Doule F.I., in Karst hydrology. A.I.H. Memoirs, vol. XII

Turc L (1954) Le bilan d'eau des sols. Relations entre les precipitations, l'évaporation et l'écoulement "Soil water balance. Relationship between precipitation, evaporation and flow". Ann. Agron. 5

White WB (1969) Conceptual models for carbonate aquifers. Ground Water 7

Zojer H, Stichler BR (1988) Groundwater characteristics and problems in carbonate aquifers, IAEA-AG-329.2/8, 159-171.

Zötl I (1974) Karsthydrogeologie. Springr Verlag. Wien-New York. 